\title{
5'-3' Exoribonuclease 1
}

National Cancer Institute

\section{Source}

National Cancer Institute. 5'-3'Exoribonuclease 1. NCI Thesaurus. Code C94707.

5'-3' exoribonuclease 1 (1706 aa, $194 \mathrm{kDa}$ ) is encoded by the human XRN1 gene. This protein plays a role in ribonucleotide metabolism. 